\title{
Mechanisms IN RECOMBINATION
}




\section{MECHANISMS IN RECOMBINATION}

Edited by

Rhoda F. Grell

Biology Division

Oak Ridge National Laboratory

Oak Ridge, Tennessee 


\section{Library of Congress Cataloging in Publication Data}

Main entry under title:

Mechanisms in recombination.

"Proceedings of the twenty-seventh Biology Division research conference held in Gatlinburg, Tennessee, March 31-April 4, 1974."

Includes bibliographies and index.

1. Genetic recombination. I. Grell, Rhoda Frank, ed. II. United States. National Laboratory, Oak Ridge, Tenn. Biology Division. [DNLM: 1. Recombination, Genetic-Congresses. QH443 011m 1974]

Proceedings of the Twenty-Seventh Biology Division Research Conference held in Gatlinburg, Tennessee, March 31-April 4, 1974

ISBN-13: 978-1-4684-2135-4

DOI: $10.1007 / 978-1-4684-2133-0$

(c) 1974 Plenum Press, New York

Softcover reprint of the hardcover 1st edition 1974

A Division of Plenum Publishing Corporation

227 West 17th Street, New York, N. Y. 10011

United Kingdom edition published by Plenum Press, London

A Division of Plenum Publishing Company, Ltd.

4a Lower John Street, London, W1R 3PD, England

All rights reserved

No part of this book may be reproduced, stored in a retrieval system, or transmitted, in any form or by any means, electronic, mechanical photocopying, microfilming, recording, or otherwise, without written permission from the Publisher 
This volume is dedicated to three pioneers in the study of recombination

CARL C. LINDEgRen

MARY B. MITCHELL

ALEXANDER WeINSTEIN 


\section{Foreword}

This book contains the papers presented at the Twenty-Seventh Annual Biology Division Research Conference which was held April 1-4, 1974 in Gatlinburg, Tennessee. The topic of the symposium was Mechanisms in Recombination and it follows by exactly twenty years the previous Gatlinburg Symposium on Genetic Recombination. During this interval, and the preceding years as well, the process of recombination has remained a central and tantalizing problem for geneticists. The subject assumes added significance with the recent appeal by a committee of leading scientists for a moratorium on the construction of certain types of recombinant molecules. That autonomously replicating molecules linking portions of prokaryotic and eukaryotic DNA can now be produced in vitro attests to the technical advances that have taken place in this field. Nevertheless, the details underlying the process in vivo continue to be elusive.

This symposium brought together individuals studying recombination in organisms as widely separated as bacteriophage and mammals and using disciplinary approaches of comparable diversity. Consequently the present volume summarizes much of current strategies and concepts concerning the subject.

The meeting was sponsored by the Biology Division of the Oak Ridge National Laboratory (operated by the Union Carbide Corporation for the U. S. Atomic Energy Commission) with the support and encouragement of its director, H. I. Adler. The organizing committee was chaired by J. K. Setlow and included R. F. Gre11, R。 D. Hotchkiss and E. Volkin. Special thanks are due to the speakers, to $I$. R. Lehman, G. Mosig, S. H. Goodga1, R. K. Mortimer, C. W. Hinton, and R. D. Hotchkiss who acted as chairmen of the sessions, and to M. J. Loop for arranging many of the details. I am happy to acknowledge the invaluable assistance of $\mathrm{C}$. L. Smith and the generous help of W. E. Cohn in the editing of this volume.

September, 1974

Rhoda F. Grel1

Editor 


\title{
Contents
}

\author{
RECOMBINATION IN BACTERIA AND THEIR PHAGES
}

Exchange of Parental DNA during Genetic Recombination in Bacteriophage $\phi \mathrm{X} 174 \mathrm{R}$. M. Benbow, A. J. Zuccarelli, A. J. Shafer and R. L. Sinsheimer

Recombination in Bacteriophage $\mathrm{f} 1 \mathrm{~N}$. D. Zinder

On the Role of Escherichia coli DNA Polymerase I and of

T4 Gene 32 Protein in Recombination of Phage T4

G. Mosig

Heterozygotes as Intermediates of Bacteriophage Recombination M. S. Fox and R. L. White

Mapping of Point Mutations on the Physical Map of Coliphage Lambda: Absence of Clustering for Odd-Numbered Exchanges F. R. Blattner, J. D. Borel, T. M. Shinnick and $W$. Szybazski

Site-Specific Recombination: Genes and Regulation

H. Echols, S. Chung and L. Green

Recombination of Phage $\lambda$ DNA in Vitro M. Syvanen 79

chi Mutations of Phage Lambda D. Henderson and $J$. Weil

In Vitro Studies of the gam Gene Product of Bacteriophage

$\lambda$ A. Karu, Y. Sakaki, H. Echols and S. Linn

Transduction of rec $\mathrm{B}^{-}$Hosts is Promoted by $\lambda$ redt Function $R$. A. Weisberg and N. Stemberg 
Transformation and Transduction of Escherichia coli:

The Nature of Recombinants Formed by Rec, RecF,

and $\lambda$ Red $W$. Wackemagel and C. M. Radding

The RecE Pathway of Bacterial Recombination $J . R$. Gizlen and A. J. Clark

Isolation of the Enzyme Associated with the $s b c A$

Indirect Suppressor S. R. Kushner, H. Nagaishi and A. J. Clark

Transformation-Mediated Recombination in Escherichia coli M. Oishi, S. D. Cosloy and S. K. Basu

Transformation of Escherichia coli by Recombinant Plasmid Replicons Constructed in Vitro S. N. Cohen

Uptake and Integration of Transforming DNA in BaciZZus subtilis D. Dubnau and C. Cirigliano

In Vitro Transformation in Toluenized Bacillus subtilis $S$. Imada and $N$. Sueoka

Transformation in Haemophilus influenzae J. E. LeClere and J.K. Setzow

On the Role of Restriction Enzymes of Haemophizus in Transformation and Transfection $R$. Gromkova and S. H. Goodgal

Role of a Deoxyribonuclease in Bacterial Transformation S. Lacks

Marker Effects in Pneumococcal Transformation J-G. Tiraby and M. S. Fox

\section{RECOMBINATION IN FUNGI}

Genetic and Biochemical Studies of Recombination in Ustilago maydis $R$. Holziday, W. K. Holloman, G. R. Banks, P. Unrau and J. E. Pugh

Genetical Interference and Gene Conversion $R$. K. Mortimer and $S$. Fogel

The Relationship Between Genetic Recombination and Commitment to Chromosomal Segregation at Meiosis $R$. $E$. Esposito, D. J. Plotkin and M. S. Esposito 
Properties of Gene Conversion of Deletions in Saccharomyces cerevisiae G. R. Fink

Lack of Correspondence Between Genetic and Physical Distances in the iso-1-Cytochrome $c$ Gene of Yeast $C$. W. Moore and F. Sherman

Recombination of Mitochondrial Genes in Yeast B. Dujon

The Isolation of Mitotic rec- Mutants in Schizosaccharomyces pombe S. L. Goldman and H. Gutz

\section{RECOMBINATION IN HIGHER EUKARYOTES}

Intergenic Recombination, DNA Replication and Synaptonemal Complex Formation in the Drosophila Oocyte $R$. F. Grelz and $J$. W. Day

Studies on Recombination in Higher Organisms A. Chovnick, W. M. Gelbart, M. MeCarron and J. Pandey

Genic Control of Meiosis and Some Observations on the Synaptonemal Complex in Drosophila melanogaster

A. T. C. Carpenter and B. S. Baker

Coincidence of Modified Crossover Distribution with Modified Synaptonemal Complexes P. B. Moens

Synaptonemal Complex Karyotyping in Spreads of Mammalian Spermatocytes M. J. Moses and S. J. Counce

An Extrachromosomal Suppressor of Male Crossing-Over in Drosophila ananassae C. W. Hinton

X-Ray and U1traviolet Light Sensitivities of a Methyl Methanesulfonate-Sensitive Strain of Drosophila melanogaster P. D. Smith and C. G. Shear

\section{MODELS OF RECOMBINATION}

Rèd-Mediated Recombination in Bacteriophage Lambda $F$. W. Stahl and M. M. Stahl

A Replicator's View of Recombination (and Repair) A. Skalka

Concerning the Stereochemistry of Strand Equivalence in Genetic Recombination H. M. Sobelz 
The Evolution of Recombination Models $R$. D. Hotchkiss

Contributors

Subject Index 